\title{
THE FORMATION OF UKRAINIAN LITERARY \\ CANON ON THE DONBASS WAR: \\ EMOTIONAL MATRICES OF NON-COMBATANTS
}

Keywords: Ukraine, Ukrainian literature, war in Donbass, emotions, non-combatants, refugees

\begin{abstract}
The article examines the representation of non-combatants in Ukrainian literature in the context of formation of a literary canon on the Donbass war. The research focuses on the literary practices instrumental in reconstructing the experience both of the displaced persons and of the civilians trapped in war zones, and aims to show how this experience is reflected in emotional matrices. We draw on the data collected during the 2016-2018 fieldwork in Ukraine, and attempt to analyze it conceptually in the perspective of the interdisciplinary field of studying history of emotions, associated with the work of William Reddy, Barbara Rosenwein, and others. By employing both anthropological and literary approaches, we explore the key texts of the contemporary Ukrainian literature on the subject of war in the East of Ukraine. We argue that the theme of experience of the civilians and the displaced persons, running through the emergent narrative canon, may come to constitute its dominant part.
\end{abstract}

This article is a translation of: Плеханов А.А., Герасимов В.К. Формирование украинского литературного канона о войне в Донбассе: эмоциональные матрицы нонкомбатантов // Etnograficheskoe Obozrenie. 2021. No 4. P. 175-190. DOI: 10.31857/S086954150016708-8

Cultural sphere of modern Ukraine appears as an area of information confrontation and comprehension of tragic events of the war in the east of the country. The most important role of a mentalist for these events and a force that was called upon to redefine friends and foes, to establish a normative framework for feeling and separate the right emotions from the wrong ones by artistic means was played by modern Ukrainian literature.

The importance of national literature and the novel as its fundamental form for nationbuilding can hardly be overestimated. It is this literary form (along with the newspaper one) that provides technical means for "representing" the kind of imaginary community that a nation is (Anderson 2016: 73). The history of Ukrainian political nation and the history of Ukrainian literature are largely identical; it is often impossible to relate the history of a nation apart from its literature history. Today we can observe the process of formation of a literary canon about the war in the east of Ukraine. As it is mentioned by A. Assman and Ya. Assman in the analysis of relations between state censorship and the literary canon, the essence of the canon is due to the structuring and narrowing of an existing tradition, from which a certain area is withdrawn, the border of which corresponds to the division into canonical and apocryphal (Assmann, Assmann 2001: 133). Therefore, the function of the canon is always social integration, consolidation of norms and meanings, as well as removal

Artemii A. Plekhanov | https://orcid.org/0000-0001-6548-0402 | plekhanov.art.alex@gmail.com | Institute of Ethnology and Anthropology, Russian Academy of Sciences (32a Leninsky prospekt, Moscow, 119991, Russia)

Usevalad K. Herasimau | https://orcid.org/0000-0002-6162-7398 | vgerasimov1989@gmail.com | Moscow School of Social and Economic Sciences (82 Prospekt Vernadskogo, Bldg 2, Moscow, 119571, Russia)

Etnograficheskoe obozrenie. 2021. № 4. P. 329-342. https://doi.org/10.31857/S086954150016803-3 ISSN 0869-5415 (C) Russian Academy of Sciences (C) Institute of Ethnology and Anthropology RAS | http://journal.iea.ras.ru 
from a certain part of the tradition, which will be designated as deviation in future. Herewith, the truth fixed in the canon, embodied in the structure and semantics of the narrative, always concerns the "truth-for-some-group". This correct observation is represented in the best way possible with the material of Ukrainian literature about war.

On the one hand, the authors claim to tell an absolute truth in their stories about the war for the entire Ukrainian society. On the other hand, a contradiction related to the actual need to build personal relationships within the framework of works within the groups, whose destinies were impacted by this conflict arises as well. Thus, the emerging literary canon is based on experience and "truth-for-some-group", which in our case are all sorts of experience and "truth" of combatants and non-combatants involved in the conflict in eastern Ukraine by the will of fate.

Having the tools for maintaining and reproducing of the canon, state cultural institutions form a social order in the same way as the solidarity of a group, which will serve as a kind of master copy of how Ukrainian society should be treated and what emotions its members should experience with regard to this conflict (Ibid: 149).

The authors proceed from the fact that literature within culture as a regulator of social life, appears as a pluralistic, multipolar space of comprehension and development of corresponding emotional matrices by representatives of emotional communities. When provided outside, these matrices can both pretend to further fixation as a national canon of patriotic feeling, and to deconstruct the co-existing auto-glorifying matrices of both foreign and native communities. In this article, we propose to consider literature (understood in a broad sense) as a field for production of emotional matrices, that further, having become part of a national literature canon about war, will de facto turn into a peculiar obligatory model of the nationwide feeling of war for future generations of Ukrainian citizens.

The authors turn their focus towards demonstration that the understanding of war in Donbass in the field of Ukrainian fiction and non-fiction literature is not internally unified and uniform. In the previous article dedicated to this topic, U.K. Herasimau has analyzed emotional matrices of Ukrainian combatants - fighters of the Armed Forces of Ukraine (hereinafter - Armed Forces of Ukraine) and members of paramilitary formations (volunteer battalions) in fiction and non-fiction literature dedicated to the war (Herasimau 2020). In this paper, we continue to study the emotional matrices of the conflict participants and shift our focus from the combatants positions to representations of the emotional world of civilians and displaced residents who had been staying in the conflict zone.

In this paper, the term "displaced residents" will mean "internally displaced people". According to current Ukrainian legislation, this term refers to persons staying in the territory of Ukraine on a legal basis and entitled to permanently reside in the country, but forced to leave or abandon their place of residence due to or in order to avoid the negative consequences of the armed conflict (Law of Ukraine 2014). In this text terms "displaced residents", "refugees" and "internally displaced persons" are used as synonyms. With regard to this definition, we do not talk about the image of refugees who left Ukraine for the Russian Federation and other countries. At the same time, it must be admitted that we did not find examples of such a description of refugees in the analyzed literary works dataset. Most likely, to examine this issue, it is necessary to study the corpus of Russian literature devoted to Donbass war, which, however, is a topic for a separate study.

We can describe the research matter of our article as follows: how the topic of the experience of non-combatants - refugees and civilians left in the military actions zone - is reflected in the works of Ukrainian literature about the war?

Thus, we will demonstrate that there is a layer of works dedicated to a drastically different experience of war along with the literary works created by the combatants. We distinguish our own classification of emotional matrices of non-combatants (including both refugees and civilians staying in the war zone) as images of experiencing and feeling war offered to the Ukrainian audience. 
From an ethnographic viewpoint, the emotional matrices spread by the literature can, to a certain extent, be correlated with the real matrices existing in real emotional communities. At the same time, their absolute identification is not correct. We face an even more complicated situation in transition to the study of the emotional matrices of civilians - noncombatants living in Donbass, who turn out to be represented either by authors who have become displaced residents, or by professional writers who did not live in the territory of Donbass during the military actions. In both cases, describing the emotional world of Donbass residents, the authors inevitably encounter the need to reconstruct their own experience and practices. Thus, the spread of the emotional matrices of Donbass non-combatants by Ukrainian literature can also be considered as the spread of matrices by professional public highbrow writers for non-combatants.

The work analyzes books, the presentation of which was timed to coincide with the largest book festival in Ukraine "Book Arsenal" in 2016-2018 and thus was provided by the publishers as some mainstream of their activities. The authors has also monitored the sites of the major booksellers and publishers: "Yakaboo", "Knigarnya $E$ ", "Family Leisure Club", etc.

In recent years, a certain body of works analyzing fiction and memoir literature about the war in the east of Ukraine has been formed. Thus, A. Portnov, in his articles devoted to Ukrainian intellectual discourses, considers the positions of Ukrainian writers as public intellectuals regarding the issue of "Ukrainianness" of Donbass and broader, of southeastern Ukraine (Portnov 2016). The scientist is interested not in literary works about the war as such, but in the political and ideological positions of their authors regarding the possibility and feasibility of the reintegration of Donbass into the all-Ukrainian political and symbolic space. His attention is focused on the figure of S. Zhadan - writer and poet, who is, by Portnov's viewpoint, personifying rejection of the so-called tradition of Galician reductionism, for the researcher, which he defines as a system of ideas that Ukraine can become successful only by eradicating the ballast of Donbass (Ibid.: 111-112). Within the narrative of Galician reductionism, the inhabitants of Donbass are obliged to bear collective responsibility for the events of the so-called Russian spring, while S. Zhadan holds the position meaning that "the population of the war-torn region should not be blamed for what was the result of outer aggression, as well as the decisions of Kiev and local elites" (Ibid: 114). Thus, Galician reductionism is a worldview dehumanizing the Donbass residents and excluding them from the imaginary community of the Ukrainian nation.

Literature scholar and historian of culture Ya. Polishchuk addresses the study of the images of Donbass and its inhabitants, embodied in the post-Soviet Ukrainian literature. In his opinion, the Donbass metaphor (as a symbolic image of the region) and metonymy (as a mode of the mentality of its inhabitants) are intimately intertwined in fiction. Considering Vladimir Rafeenko's "A Brief Book of Farewells" and Aleksey Chupa's "Tales of My Bomb Shelter" collection of stories as an examples, Ya. Polishchuk concludes that under the mask of "wildness and exoticism" the characters of the books hide "alienation and self-isolation, cowardice and brutality ... fear and helplessness, inertia and lack of will to change in life" in themselves" (Polishchuk 2018: 14). According to the researcher, such a "inconsistent metonymy" means the essence of the "metaphor of Donbass" as "a metaphor of existential emptiness that arose in the place of the destroyed Soviet myth " (Ibid: 19). Therefore, the author represents that type of the Ukrainian literary understanding of Donbass, within which this region emerges to be an existential failure and, in general, an area of Ukrainian catastrophe. Such "soft" stigmatization is an acceptable option in the Ukrainian academic debate. From our viewpoint, such vision speaks more about the reaction of public intellectuals to the failure of Ukrainian nation-building than about the essential characteristics of Donbass as the Other.

In the cases mentioned above, the research interest in the literature about the Donbass merely indirectly affects the emotional sphere. However, one should not overlook the paper by I. Gomza and N. Koval, in which they, while analyzing the role of emotions as 
Euromaidan participants political mobilization factor, emphasize the importance of emotional union of its participants. Interaction through shared positive emotions created an image of community, and imagining oneselves as moral actors was critically important both for antagonists (to oppose themselves) and those who stayed at a distance from the conflict (Gomza, Koval 2015: 58).

In the presented work, the authors rely on the theoretical and conceptual apparatus of such interdisciplinary research field as the history of emotions, developed by W. Reddy, B. Rosenwein and A. Zorin, namely, on the set of concepts "emotional regime", "emotional communities" and "emotional matrices".

According to W. Reddy, an emotive is understood as a type of speech act that simultaneously describes and changes the world through emotional expression. Political regimes in their activities rely on "emotional regimes" as a set of normatively prescribed emotives spread through official practices and rituals (e.g., emotive of a public declaration about love for the motherland). The inability of the individual to meet the requirements leads to the experience of "emotional suffering" and the search for "emotional refuge" by the latter (Reddy 2001: 124-129; Zorin 2016: 17; Plumper 2018: 418-419; Rosenwein 2010: 22).

According to B. Rosenwein, emotional communities are the groups within which members share common interests, values and goals. With the common social background of their members, emotional communities are characterized by the nature of affective relations between them, by the set of certain emotions that they value, devalue or ignore, by encouraging or blaming certain modes of emotional expressiveness (Rosenwein 2006: 24-26; 2010: 11). Existence of emotional communities is directly related to development of emotional matrices, seen as images of public expression of emotions (Rosenwein 2006: 25; Zorin 2016: 30).

Thus, we have methodologically singled out the emotional matrices of non-combatants in the Ukrainian literature works, having created a representative sample of literature works at the first stage. Further we proceeded to consider the descriptions of emotional states they contained, associated with the examined groups of population. Further, the most significant and frequently mentioned descriptions of such emotional states of the heroes of the works were noted as public manifestations of particular experienced feelings. We do define such public displays of feelings, that set the hierarchy of a decent and indecent emotions combination, as emotional matrices. Our further task will be to conceptualize the essence of these matrices as the presented normative behavior scenarios.

\section{Emotional matrices of immigrants: strangers among their own}

There is two emotional matrices prescribed to the displaced residents that can be distinguished in the Ukrainian literature about the war, namely the matrices of "conflict-free integration" and "failed acculturation".

The matrix of conflict-free integration is related to the stories of successful adaptation of a refugee in a new location. A bright example of the embodiment of this kind of matrix can be seen in the books written by writer-migrant from Luhansk Margarita Olegovna Surzhenko. In Surzhenko's semi-autobiographical story "ATO. Stories from East to West", that has stayed in the top 20 of the bookstore "Knigarnya " $E$ " for several months, there is a character Angelina who has found a new, better life. Enchanted by the Western Ukrainian rural flavor, she gets in a village of Ivano-Frankivsk region "a wonderful opportunity to get to know the real Ukraine" and understand "what it means to wholeheartedly love it". Another character in the story, Oksana, starts a freelancer job and donates money to the army. The third character, Tolik, after being wounded and demobilized from the "Aydar" volunteer battalion, gets a job in a Kiev IT firm and, like Oksana, finds his new vocation in helping the army. All her heroes, not only without regret, but also happily leave their previous lives in the past, find a new home in the cities of Central and Western Ukraine and go together to the "Okean Elzy" 's concert in Lviv on Independence Day (Surzhenko 2014). 


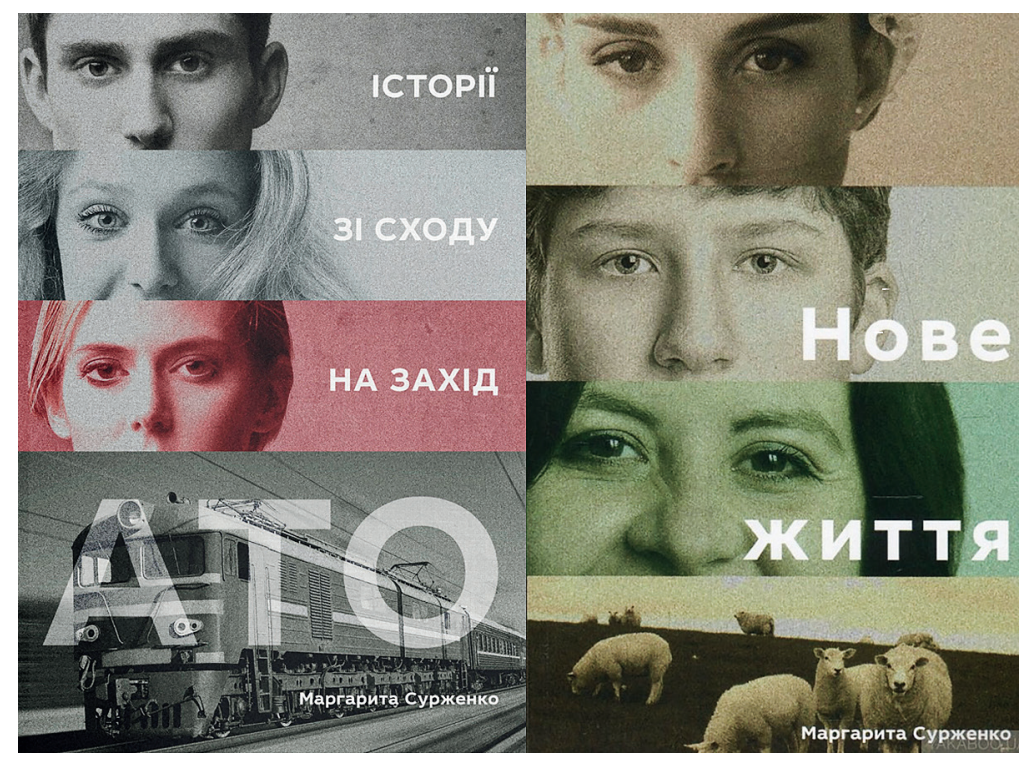

Fig. 1. Covers of the book by Margarita Surzhenko "ATO. Stories from East to West" 2014 and "A New Life. Stories from East to West" published by "Discursus"

The emotional matrix of conflict-free integration is also demonstrated in the prose of the writer and journalist Yevgeny Polozhy. Thus, a schoolboy whose father was wounded near Ilovaisk describes his natural and uncontested patriotism: "We have no choice. All our belongings, down to socks, remained in Donetsk... My father and I rent a one-room apartment near Zhitomir. He's going to war, and I'm going to a new school. I shall live here. That is the main thing I wanted to say" (Polozhiy 2015: 136).

A displaced resident Pasha from the city of Snezhnoe, agrees to help return the body of a deceased Ukrainian soldier to his family risking his own life. The hero of the novel gained prison experience in youth (he robbed booths), but, despite this, Pasha is depicted as a brave and decent person, ready to risk his life not only for money, but primarily due to the desire "to become useful and necessary in a new life, among people that are unfamiliar and sometimes strange to him". He has no other nearest people left: his mother and father cursed him due to his convictions (he spoke for "united Ukraine"), his "Donbass folks" thought him an enemy (Ibid: $211-213,217)$.

This emotional matrix paradoxically reveals resemblance to the forms of socialist realism as a creative method. In such works, the heroes act and live as per the description by A. Sinyavsky of the positive characters in the socialist realist novel - "devoid of shortcomings or slightly endowed with them, to preserve some human likeness, and also to have the prospect of something in themselves to get rid of and develop, raising their moral and political level more and more. They know too well what is good and what is bad, there is no inner doubt and hesitation for them" (Tertz 1988: 25). The events that forced them to move turn out to be those necessary trying times and hardships of life, having overcome which they become honorable society members and Ukraine patriots.

The second emotional matrix can be denoted as "failed acculturation". It is characterized by feelings of suffering and seeking an emotional shelter, whether it be dreams about returning home or hedonism. In 2015 Surzhenko publishes the story " A New Life", where the first part of the dilogy is deconstructed. In this book, the life of Olga, a refugee from Luhansk, turns out to be not as rosy as that of her brothers and sisters in misfortune in the 

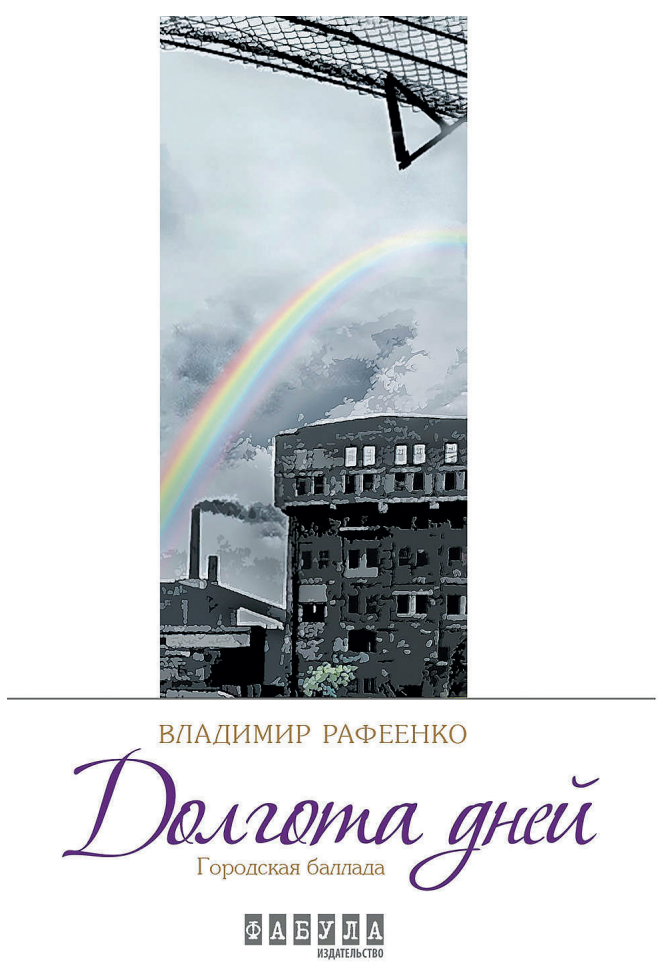

Fig. 2. Cover of the book "Longitude of Days" by Vladimir Rafeenko, published by "Fabula" publishers in 2017. story of 2014. The greeting "Glory to Ukraine" arouses hatred in the heroine at first, as well as entire Kiev surrounding her, while the hope of returning to Luhansk, on the contrary, makes her feel happy (Surzhenko 2015: 46, 50). After an unsuccessful attempt to return, Olga finds herself forced to deceive a patriotic businessman in love with her, by pretending to be a patriot of Ukraine in a hostile environment. Despite that Kiev ceases to be alien to her, she still face revelation and lose her love, thereby paying the price for insincerity and an attempt to conceal her "wrong" past (Ibid .: 203-205). Another character of the writer, Katya, a refugee from Luhansk too, having moved to Kryvyi Rih, abruptly, separates her life from the ongoing war: "The war is left there! There is no war here! ... The war is there, and we are here! ... We had enough of it all, shooting at night, explosions! We have the right for rest!". In her opinion, the "maidauny" " who "started" the war should be responsible for it, and her boyfriend's desire to go off to war as a volunteer causes her categorical rejection, leading to an ending of a relationship (Surzhenko 2014: 32-35).

Bitterness due to the discrepancy between the shared emotives of the "native" Ukrainians and the Ukrainians who "returned" to Ukraine from the war area is also depicted as mutual. It is the reluctance, and often inability of people that fled from the territory of military actions, to correspond to the generally accepted Ukrainian patriotic emotional regime that causes a sharply negative reaction in residents of settlements to which refugees from Donbass have arrived. Personal failed communication experience only reinforces pre-existing prejudices about the "Donbass people". In his collection of stories, E.V. Polozhy describes the reaction of Stas, the son-in-law of the dead soldier's mother, as follows: "I know these folks! They sit here, munch, get social services, but hate us!.. I don't get it. Did they earn little money in Ukraine? Did the live badly? Well, they did better than the rest of the country! What was it all necessary to start for, f. to run to referendums? For people to die? What did they miss? (Polozhy 2015: 210).

For the journalist and writer Ruslan Vladimirovich Gorovy, such situations are a reason to stress the otherness and foreignness of the Donbass residents who became refugees. In one of his stories, a woman who speaks very loudly in Russian in public vehicle and demonstrates close acquaintance with a separatist and disregard for the relatives who sheltered her, becomes a target of a joke on the part of the narrator. He depicts a telephone conversation with

* Maidauny (Rus. Майдауны; Ukr. Майдауни) is an insulting name for the part of the Ukrainian society that supported the protest on Independence Square (Maidan Nezalezhnosti) in Kiev in 2013-2014. This concept is formed from two words. The first part of this concept, "Mai", comes from the Ukrainian word «Maidan» (translated as "square"). The second part of the word, "dauny", refers to persons with Down syndrome. 
the battalion commander of a Donbass volunteer battalion and allegedly asks the "battalion commander" on behalf of the woman to admit her husband and son to the battalion, and send her personally "closer to the ATO" to the field kitchen. Naturally, the woman is shocked and runs out at the nearest stop (Goroviy 2016: 33).

Thus, the figure of a refugee in the literature about war is revealed via the opposition of these matrices. If the characteristics of the emotional matrix of failed acculturation are the desire to abstract from the war, local regional patriotism, the value of memory of the past, reluctance to integrate into new emotional communities, willingness to mimic to ensure compliance with the official patriotic emotional regime and/or seek "emotional shelter", then the emotional matrix of conflict-free integration is revealed through the still Soviet tropes of a positive hero, characterized by a willingness to consciously become a combatant or volunteer, admiration for Kiev, cities and villages of Western Ukraine as "true Ukraine", the desire to integrate into new, not wrong but right emotional communities.

Unfortunately, we recorded no more works related to the purely emotional matrix of failed acculturation. One may assume this is due to the extreme painfulness of recognizing the existence of the refugee integration issue.

A peculiar synthesis of these matrices can be seen in the novel "The Length of the Day" by the famous Russian-speaking Ukrainian writer Volodymyr Rafeenko. Forced to become a refugee and leave his native Donetsk, the author makes the protagonists of the novel magical displaced residents who, without leaving their Donbass identity and being at the same time patriots of Ukraine, act as agents for replacing the exclusive intra-Ukrainian emotional regime with a more inclusive one.

Two storylines run through the narration. One of them tells about the $\mathrm{Z}$ city (implying Donetsk), which, due to the intrigues of Russian political engineers, was magically attached to the non-existent USSR. All its residents, in fact, are dead and deprived of the opportunity to escape from this curved chthonic area. The only way to escape from $\mathrm{Z}$ and resurrect in ideal Ukraine in the novel is death. Otherwise, when attempting to get to Ukraine alive, bypassing death in $\mathrm{Z}$, a person will be met either by corrupt clerks or ethno-nationalists who hate him/her, and then he/her will wake up again in Z. In other words, Rafeenko postulates, there are only two existential options for civilians - either a posthumous life in Ukraine, or an intravital death in $\mathrm{Z}$.

The main characters of the novel - Sokrat Gredis, Nikolay Veresaev and Liza Eleonora sacrifice their lives twice: first when going from $Z$ to Ukraine, and then in Kiev, where they die for the sake of reuniting a new, "non-Soviet" and "non-Russian", purified Z, with a renewed Ukraine void of corrupt elites and ethno-nationalist myths (Rafeenko 2017: 256, 260,276 ). Thus, the impossibility of identifying people who escaped from $\mathrm{Z}$, having extremely traumatic practices of lifetime death and posthumous life, is manifested, with an exclusive emotional regime supported by the Ukrainian political elite in 2017. "Otherness" of displaced residents who have become martyrs and patriots serves for Ukraine as a way to find its ideal self. The second, built-in, plot line uncovers in a number of unrelated short stories, which one of the heroes, Nikolai Veresaev, writes, in the novel. These stories, void of any convention, harshly and even brutally illustrate real experience of survival and/or sudden death in the city where one does not know whose shell will strike your house or bus. Thus, Rafeenko, on the one hand, breaks with his own hands through the wall of magical realism, in which the main narrative of the novel develops, on the other hand, he shows the reader that a terrible magic fairy tale is not a fairy tale, but the reality itself.

One of the central short stories from the novel, "Beer and Cigarettes", which provides an idea of the existential experience of the Donbass summer 2014, was published in "Znamya", one of the most important Russian literature magazines. Thus, the pain and horror of the war were demonstrated not only to the Ukrainian, but also to the Russian reader, thereby acting as an specimen of humanism in literature, when empathy prevails over trying to understand whether or not a defenseless human is on the "right" side. At the same time, 
according to Rafeenko, the publication of this novel, due to the clearly expressed position regarding the persons responsible for the war outbreak, buried the possibility of publishing his texts in Russia (Abibok 2017).

\section{Donbass as the Other: Emotional Matrices of Civilians in a conflict zone}

Authors whose works relate to war, not merely reconstruct the emotional matrices of own emotional community, as it happens with the emotional matrices of combatants (Herasimau 2020: 183-184), but also, guided by their own hypotheses about the matrices of other emotional communities, inscribe their experience into the process of creating images of how other people feel. Accordingly, in the works about the war in eastern Ukraine, the most important place is provided to the building and reconstruction of matrices attributed to non-combatants in the front-line territories.

A fighter of "Azov" battalion ${ }^{3}$ with the call sign "Voland" describes his stay in Mariupol as a trip in a time machine to the USSR: "It didn't feel like Ukraine at all ... Time stopped here ... everything remained at the level of the 70s" (Call sign "Voland" 2016: 73). Ordinary fighters create an image of the otherness and distinctiveness of Donbass in their memoirs to oppose themselves to it and its residents.

We see the use of alienating tropes about local population, which is exoticized and is put in the position of a caricatured aborigine. This colonial logic ascribes irrational thinking, inability to perceive "correct" values, primitive admiration for power, wretchedness and infantilism to the residents of Donbass. All these features, according to the authors, can be corrected by the Ukrainian combatants who have arrived in Donbass:

The people without understanding of such simple words as self-organization, solidarity, honor and pride. They will never be side by side with us ... These people are not used to human relations. They need a power that will push them down so hard that they won't get up, which will think them nothing, with which they will not decide anything and they can calmly plunge into their world of longing and despair, anger and hatred, looking for enemies everywhere, but not among themselves (Ibid: 73-75)

These people only have a special mentality. They were unable to understand the situation and rational arguments, they respected only force (Call sign "Viriy" 2017: 82).

I see a huge number of Muscovites, whose grandfathers and fathers came in large numbers to Ukraine, to the Ukrainian lands depopulated by hunger. Those Muscovites were and remain Moscow patriotic chauvinists. These Moscow chauvinists were provided with citizenship by our Ukrainian, but essentially Muscovite, government in the early 90s. It is impossible to redeem them. They can be pacified only (Bilina 2016: 79).

At the same time, Voland and a number of other combatants admit in their memoirs that not all the residents of Donbass are equally against Ukraine. There also were people who rejoiced at the arrival of the battalion or even actively assisted to search for separatists (Call sign "Voland” 2016: 70-71). The author does not interpret such behavior as a desire to adapt to the new power - it is more important for him to perceive this as a manifestation of sincere Ukrainian patriotism. Thus, a zero-option negative view of Donbass non-combatants coexists with the belief in the existence of "correct" civilians.

In contrast to the combatants' position, the view of writers and journalists has less radical vision in relation to the Donbass residents. Their works bring the situation of ambivalence of worldview and political orientations to the fore. Emotional matrices attributed by Ukrainian literature to Donbass non-combatants turn out to be fundamentally irreducible just to the confrontation between separatist proponents and Ukrainian patriots. Thus, we single out three main emotional matrices.

Non-combatants who insult, hate and threaten Ukrainian soldiers, as well as those who heal them, feed them, shelter them, direct them out of the encirclement, remains faithful to 
the state symbols of Ukraine and refuses to work in state institutions of the "people's republics", possess an emotional matrix that can be characterized as sympathizer's. Within it, a civilian experiences bright emotions, such as anger, contempt, hatred, anger, towards one of the warring parties and, on the contrary, emotions like admiration, a sense of solidarity, love - towards another, identified as "our folks". The choice of objects for positive/negative emotions is a derivative of the political position taken.

At the same time, the sympathizer emotional matrix has two features. First, inside it as an exception, absence of negative emotions towards one's political opponents remains possible. Ukrainian literature has already created an image of noble supporters of the DPR not hating Ukrainian Armed Forces. People who do not want to see "Ukres" on their land, who use the pronoun "your" in relation to the Ukrainian troops, nevertheless can help the Ukrainian soldiers.

In the collection of stories "Ilovaisk. Stories about real people" by E. Polozhiy where documentary prose combines with artistic reconstruction, one of the characters, chief physician Alexei Ivanovich, "the main separatist in Amvrosiivka", conscientiously treats a Ukrainian soldier of the Ukraine Armed Forces having the call sign

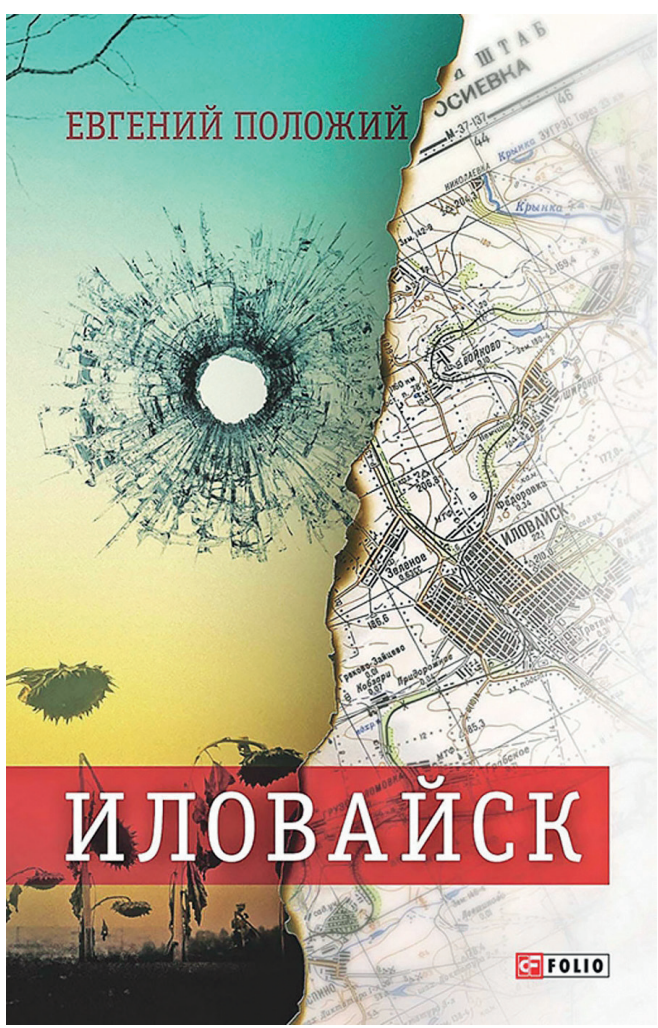

Fig. 3. Cover of the Russian edition of the book "Ilovaisk. Stories about real people" by Evgeny

Polozhy, published by the "Folio" publishing house in 2015 .

"Kaban" who was admitted to his hospital and does not prevent the medical staff from covering him. As a result, the grateful Ukrainian fighter is frustrated and does not understand "how such a person can support the DPR" (Polozhiy 2015: 44, 52, 61). Secondly, a change in political orientation appears possible. Nurse Vikusya, who sympathized with Ukraine and rescued the Ukrainian fighter, goes to the DPR militia forces after a while:

- And where is Vikusya? ... - She left with secessionists. - How did she? - As a nurse. How did it happen? It is impossible! She stands for Ukraine! - So simple. Got together with Chechen mercenary, fell in love. They don't pay enough money in the hospital anyway, the town is small, it's hard for such a girl to live here... it's so difficult and boring. No family, no prospects, no hopes for a better life either.

And on the other side there is love, war, romance like in a movie, they promise four thousand a month. So why do not go? (Ibid: 59-60)

In the war situation, especially the one that can be understood as a civil war, political loyalty can change, and the image of the enemy is not provided once and for all, but empathy, concern and active assistance to one of the parties will remain. The hero, changing due to certain existential circumstance the side of the conflict and his/her political identity, remains the bearer of the sympathizer matrix, continuing to demonstrate concern and active involvement in what is happening. 
The second emotional matrix unfolds through refusal to identify oneself through political loyalty to Ukraine/DPR/LPR, willingness to provide assistance and enter ally with the combatants of the opposing sides and, most importantly, through the desire to maximize own benefits. We denote it as a beneficial matrix. Its emotional content is indifference to the political background of the events and the orientation of positive emotions of solidarity and love not to political communities, but to own family and relatives. It is embodied in the greedy "iguana" taxi driver worried about his own brother, described in the S. Zhadan's novel "Boarding School". It's him who guides the protagonist to the town abandoned by the Ukrainian army. A person who does not associate himself with any of the conflicting parties but risks his life at the same time, providing the necessary function of movement between the worlds divided by a front line. This specific position of mediator and the absence of political identity are fundamental characteristics of his existence.

A man "in an oversized leather jacket, shabby and broken as if he were sleeping in it, as if it were his own skin, like an old iguana in a zoo", looks as inconspicuous as can be, but at the same time makes the interlocutor feel that it is not poverty or negligence before him, but a diligent camouflage. In other words, the taxi driver aspires to dissolve in the surrounding landscape and not to attract attention. He knows "that there are one hundred and twentyfive options to cross" the front line "and "go back"... He has already made two trips in the morning, having gone around all the checkpoints and scolding all the generals. And what they show on TV is completely different, and he does not watch it at all, because there's nothing to watch there". He does not care about the sovereignty of Ukraine or the DPR independence:

....and he says that there are no roads, there are no roads, the roads just got $f . .$. up, f... up and that's it, and there are no roads now, and there weren't any roads before, and now there are no roads. <.> And so he gets angry and nervous, and says, they say, the roads and the military people, and they f... up it all, and the brother sits in the town in a basement, together with his nearest ones, and doesn't want to get out of there, afraid to leave the building, but what about the building? - he asks Pasha, who the hell needs that building, and the roads, he says, the roads are f,, up (Zhadan 2017: 47).

Along those roads, which he knows "as his own body," he is ready to ride again and again past the gunners, "carefully bypassing" a burnt tank with corpses inside (Ibid: 56-57). S. Zhadan demonstrates that for some residents of Donbass, death, war and catastrophe have become part of everyday landscape and their life strategies are reduced to survival, and not to taking one side or another in an undeclared civil war.

A similar figure of a taxi driver is present in the documentary stories of a soldier of the "Dnepr-1" battalion Roman Zinenko and the already mentioned journalist Yevgeniy Polozhiy. Taxi drivers, endowed with more agency, demonstrate humanism and help Ukrainian military troops trapped in the "Ilovaisk kettle" to get out of the encircling. They are ready to ask questions - "who needs the war?" and "why did Ukraine start it?" and admit that they dreamed of "greater independence from Kiev", "Crimean scenario", imaginary USSR and therefore voted for the DPR, but the arrival of the Russian army shocked them. They do not want war and are ready to take the wounded Ukrainian soldiers to the nearest checkpoint of the Ukraine National Guard for free (Polozhiy 2016: 119-121; Zinenko 2016: 251-253).

However, we find a detailed description of indifferently consuming perception of the warring parties within the framework of the beneficial emotional matrix not only in the image of taxi drivers. The autobiographical "Point Zero collection of stories by the Ukrainian Armed Forces fighter Artem Chekh" gives a very detailed and thorough description of it:

Local people call us "lads". We are all lads for them ... (italics by A. Chekh. - A.P., V.G). They come up to us, ask for money in a business-like manner, usually ask "when will it end" and preach something looking from the heights of their Donbass convictions. There is 
something neutral in this word lads, neither here nor there. And characteristically, when talking about people fighting on the other side, they also use this word. All of us both militias and the Ukrainian Armed Forces - are the same for them. Now we are here, we are their bread, their sausage and their Turkish jeans. No tenderness, sympathy, gratitude - a business approach only, just business (Chekh 2017: 139-140).

Here again we face a special emotional regime, in which emotions about the parties to the conflict are abated and all the aspirations of a layperson are reduced to providing for himself/herself and his/her family, which is typical for conflicts that can be perceived as a civil war.

Within the third emotional matrix, non-combatants also do not identify themselves through political views, but, unlike "beneficiaries," they have no selfish motives. They are a kind of aimless simpletons, whose fault is that they had withdrawn at decisive moments, had refused to choose their side, and thus submitted their present and future to others. This emotional matrix can be denoted as "observing".

Perception of the war by local residents appears paradoxical, not fitting into either the Ukrainian state discourse of the "Donbass occupation" or the separatist discours-



Fig. 4. Cover of the book "Boarding school" by Sergey Zhadan, published by the "Meridian Czernowitz" publishing house in 2017. es of "return to Russia" and "independence war". Ukrainian combatants describe shocking examples of how local residents (in Ilovaisk in particular) perceived the military fight unfolding in the streets of their cities as some kind of a theater performance or movie shooting process. We see this pattern most distinctively in Zinenko's prose. The author describes the realities of urban fighting on August 26, 2014, when the picture of the battle began to turn obviously not in favor of the Ukrainian forces and the fighters of the Dnepr-1 battalion held defense in a school building, being shelled from mortars and grenade launchers, as well as shot by snipers. So, at this moment Zinenko records "one amazing point", as he himself calls it:

I noticed one striking feature in the behavior of some local residents for the first time. Subsequently, I have observed a similar picture many times ... In the very full swing of the battle, when there was a serious firefight, no farther than in the next block some local residents, were poking around in their yards and gardens as if nothing happened. It seemed people were in some other dimension. As if there was a pavilion with decorations and some action movie was being filmed, and the local population was watching the actors play with interest. It was as if there were no explosions and destruction, and these people absolutely did not feel actual danger. Two opposing forces are fighting for life and death, and a man in the street rides his bicycle and thinks that the events do not concern him at all. He is not a party to the conflict and believes that nothing threatens him (Zinenko 2016: 162-163).

In the novel "Boarding School" by S. Zhadan, the object of moral conviction is precisely the observing, and not at all the beneficial emotional matrix. A Donbass's apolitical 
layman transformation into a the self-understood patriot of Ukraine and the replacement of the observing emotional matrix with a pro-Ukrainian sympathizer serves as the main messages of the novel. The main character Pasha, 35-year-old teacher of the Ukrainian language, in the beginning identifies himself as "budget employee" who works as a tutor and represents himself to others, including the combatants of both sides, through the status of the teacher that he considers neutral to be neutral. His own life of a teacher of Ukrainian, who speaks Ukrainian only during lessons, is the life of an observer and a weakling, unable to take responsibility neither for the pupils entrusted to him nor for himself. He is not interested in politics and is not willing to know about the unfolding war.

When the front line moves close to the town, Pasha turns to be unable even to leave, instead repeating like a mantra that his teacher's status will allow him to continue to be an observer:

Pasha tried to calm everyone down ... he said they had nothing to fear if something happened, that they had nothing to do with it, they did not support anyone, Pasha was just a teacher, just a teacher, he repeated, as if apologizing for this, just a teacher, everything else was of little interest for him. Where would he go, who was waiting for him, what would they be afraid of, everything was fine, he was just a teacher (Zhadan 2017: 101).

But suddenly he has to go to the city, which turned out to be across the front line, for the nephew who remained in the boarding school. And this journey irreversibly changes him. Self-complacency is replaced by a piercing realization that his own former pupils are fighting against him:

How could it happen? How did I fail to notice that my pupils are now fighting against me? How did I miss it? Though, he tries to calm himself, why against me? Not against me. What does it have to do with me? Come on, not against you, he immediately disagrees with himself, it is clear that exactly against you, particularly against you. Against everything that is related to you. What is related to me? - Pasha does not understand himself. Yes, everything, he answers himself, and your subject, and your school, and the flag hanging above it. They are fighting for it. More specifically, against it (Ibid: 254).

At the end of the novel, having overcome numerous hardships and threats, having returned his nephew home, the matured Pasha looks into the eyes of a Ukrainian military man and says his school is at the station, and the station is "ours" (Ibid: 302). The process of emotional matrix changing from the observing to the sympathizer's has been performed.

In 2014-2018 Ukrainian fiction has created a number of works, on the basis of which several emotional matrices can be distinguished as the proposed images of the experiencing of war by various groups of population, in particular by the Donbass non-combatants. Experience of displaced residents is described through emotional matrices of conflict-free integration and failed acculturation, and the experience of civilians, living in the war zone through a beneficial, sympathizer's and observing emotional matrices. Confrontation between sympathizer's and observing matrices is the main line of the plot conflict in the works about the Donbass non-combatants. Speaking about the extremely negative perception of non-combatants by fighters of paramilitary formations, it can be mentioned that a Donbass resident often acts as an objectified Other for them, against the background of which heroic self-identification is performed.

Over the past years, the bulk of literature about the war has been replenished primarily with diaries and memoirs of the veterans of Ukraine Armed Forces and paramilitary formations. One of the problems faced by Ukrainian writers is related to the fact that the Ukrainian literary canon practically has no samples demonstrating the emotional modes of feeling 
the experience of refugees. As a result, the writers who started talking about refugees and civilians in a civil war situation appeared to be pioneers de facto, in reconstructing the emotional states of non-combatants.

It should be noted that the ongoing processes of creating a literature canon for the war are ambivalent with regard to the pre-war processes of nation-building in culture in general and literature in particular. The war, of course, triggered crystallization and strengthening of the exclusive ethno-nationalist understanding of the nation, which was widely reflected in a number of works by combatants, primarily veterans of volunteer battalions. At the same time, a few works demonstrate the stupidity and fallibility of a priori dehumanization and marginalization of Donbass residents, acting as a guide of the agenda of not ethnic, but civic nationalism, that allows bilingualism in particular. Thus, coexistence of two oppositely directed tendencies is evident.

Nevertheless, we assume that fiction works, where the main characters are not military staff, will have more chances in future to enter the history of Ukrainian literature and the Ukrainian literature canon. This is due both to the greater artistic value of these works, and to the fact that they do not show to the reader a one-dimensional picture of the struggle between good and evil, but recognize the possibility of having an ambivalent experience of war. Writers like Sergei Zhadan and Volodymyr Rafeenko do not go in their works, to the extreme of dehumanizing those individuals who have ceased to be loyal to the Ukrainian state and supported the unrecognized republics. Alongside their moral condemnation, the authors, nevertheless, do not offer readers to perceive them as totally Other, showing us a palette of human destinies in war that is much larger compared to veteran prose. Representing war picture as multidimensional and not reduced to a simple confrontation between friends and foes, they present a more humanistic and inclusive Ukrainian patriotic discourse. This kind of vision, that makes it possible to include a sympathetic view of Donbass civilians in the literary canon, regardless of their political convictions, is strategically promising as a symbolic tool for the conflict resolution.

At the same time, the representation of non-combatants is only a reconstruction by literature professionals for mass readers - Ukrainians and literary critics. The experience of displaced residents and local residents for the most part turned out to be culturally appropriated, and its return is possible only in complex phantasmagoric works, such as, for example, the novel "The Length of the Day" by V. Rafeenko, that show the confused world of displaced residents, where overcoming the political differences is possible only through an existential break from previous life. The further destiny of the canon, in our opinion, has not yet been determined and will depend on the position of key players in Ukrainian state culture institutions, the future course of Donbass war and the success of its adjustment processes.

\section{Notes}

${ }^{1}$ Speaking of modern Ukrainian literature, we also mean the works of the literature of Ukraine in Russian. In fact, the division line between Russian and Ukrainian literature is not based on language, but on the basis of ideological interpretations of the war in the east of Ukraine.

${ }^{2}$ Some changes were made to the law of 2021, incl. concerning the conceptualization of the notion, as a result of which its wording differs from the ont presented in the original version of the law in 2014; however, the meaning of the definition remains unchanged.

${ }^{3}$ The organization is prohibited in the Russian Federation.

\section{References}

Assmann, A., and J. Assmann. 2001. Kanon i tsenzura [Canon and Censorship] In Nemetskoe filosofskoe literaturovedenie nashikh dnei [German Philosophical Literary Criticism Today], edited by I.P. Smirnov, D. Uffel'man, and K. Shramm, 125-155. St. Petersburg: Izdatel'stvo SanktPeterburgskogo universiteta. 
Anderson, B. 2016. Voobrazhaemye soobshchestva. Razmyshleniia ob istokakh i rasprostranenii natsionalizma [Imagined Communities: Reflections on the Origin and Spread of Nationalism]. Moscow: Kuchkovo pole.

Gerasimov, V. 2020. Emotsional'nye matritsy ukrainskikh kombatantov v khudozhestvennoi literature ob ATO [Emotional Matrices of Ukrainian Combatants in Fiction about ATO]. Neprikosnovennyi zapas 1 (129): 180-194.

Gomza, I., and N. Koval. 2015. The Winter of Our Discontent: Emotions and Contentious Politics in Ukraine during Euromaidan. Kyiv-Mohyla Law \& Politics Journal 1: 39-62. https://doi. org/10.18523/kmlpj52673.2015-1.39-62

Palmer, Ya. 2018. Istoriia emotsii [The History of Emotions]. Moscow: Novoe literaturnoe obozrenie.

Polishchuk, Ya. 2018. Metaphoric i metonimiia Donbasu [Metaphor and Metonymy to Donbass]. Kritika 1-2: 12-19.

Portnov, A. 2016. "Donbass” kak Drugoi. Ukrainskie intellektual'nye diskursy do i vo vremia voiny ["Donbass" as Another: Ukrainian Intellectual Discussions before and during the War]. Neprikosnovennyi zapas 1 (110): 103-118.

Reddy, W.M. 2001 The Navigation of Feeling: A Framework for the History of Emotions. Cambridge: Cambridge University Press.

Rosenwein, B.H. 2006. Emotional Communities in the Early Middle Ages. New York: Cornell University Press.

Rosenwein, B.H. 2010. Problems and Methods in the History of Emotions. Passions in Context: International Journal for the History and Theory of Emotions 1: 1-32.

Terts, A. 1988. Chto takoe sotsialisticheskii realizm [What is Socialist Realism]. Paris: Syntaxis.

Zorin, A. 2016. Poiavlenie geroia. Iz istorii russkoi emotsional'noi kul'tury kontsa XVIII - nachala XIX veka [The Rise of a Hero: From the History of Russian Emotional Culture, Late $18^{\text {th }}$ Century and Early $19^{\text {th }}$ Century]. Moscow: Novoe literaturnoe obozrenie. 